\title{
Online Marketing of Baby Care Products in India
}

\author{
Aswathy.R, K.S Chandrasekar
}

\begin{abstract}
India has emerged as one of the most preferred destinations for the manufacturers and marketers of baby care products. The growing population in the 0-4 year category provides tremendous opportunities to the baby care product marketers worldwide. The favourable changes happened in the demographic and lifestyle aspects of Indian consumers have largely supported the rapid growth witnessed in the industry. With the advancements in modern technology and internet retailing, customers are able to make their purchases around the clock, without facing the constraints of time and place. Penetration of internet even to the rural India and the increased internet user base has widened the scope of online marketing of baby care products. Customers who buy products for babies are often found to be keen in searching sufficient information about the products before they take a decision with respect to their purchase. Online marketers have enabled the customers in searching, comparing and selecting the best suitable product for their babies at their convenience. Understanding the strength, weakness, opportunities and threats will help the marketers to achieve sustainable competitive advantage through effective strategy implementation.
\end{abstract}

Keywords: Baby care industry, SWOT Analysis, Online marketing.

\section{INTRODUCTION}

$\mathbf{B}_{\text {aby care market in India is growing at a fast pace and }}$ this phenomenal growth can be attributed to favourable shifts happened in the demographics and consumption style of Indian consumers. Baby care products comprises all products that are meant for meeting the day to day needs of the babies, generally falls in the age group of 0-4 years. Parents are keen to offer their child the best available products to ensure their comfort and healthy growth. Typical categories of this segment are skin-care, hair care, baby food, toiletries, apparels \& footwear, toys, baby convenience and safety products etc. Rising awareness and availability as well as the growing number of urban affluent consumers with nuclear families are increasing the spending on baby and child-specific products. Baby and child-specific products is expected to grow at a CAGR of $8 \%$ with sales set to reach INR29.4 billion in 2021. Similarly, e-commerce market in India is witnessing high growth and it can be attributed to factors such as high internet penetration, increasing

Revised Manuscript Received on July 22, 2019.

Aswathy.R, Institute of Management in Kerala University of Kerala, Thiruvananthapuram, India, Email:achu221@gmail.com

Dr K. S Chandrasekhar, Institute of Management in Kerala University of Kerala, Thiruvananthapuram, India, Email:kscnair@gmail.com smartphone users and online shopping preference of consumers. Internet users in India are expected to increase from 432 million in 2016 to 647 million by 2021 as per Deloitte Report, 2017.

\section{OBJECTIVES OF THE STUDY}

1. To analyze the emerging trends in the online baby care market in India

2. To analyse the SWOT in the Indian online baby care Market.

\section{SIGNIFICANCE OF THE STUDY}

The baby care segments, which mainly consists of products meant for catering the needs of 0-4 year age group is growing fast and provides immense opportunities to the marketers. Advancements happed in the technology together with life style changes and other favourable shifts happened in the Indian consumer profile, has created a sufficiently huge online consumer base. Hence in the back drop of rapidly growing baby care segment and increased online shopper base in India, it is imperative to understand the emerging trends, strength, weakness, opportunities and threats (SWOT) involved in the online marketing of baby care products in India.

\section{METHODOLOGY}

Only Secondary data has been used for the purpose of the study. Data from journal articles, books, industry reports, and other published and unpublished records has been used for collecting data needed for the study.

\section{INDIAN BABY CARE MARKET-AN OVERVIEW}

India is the second largest populous country after China with a population of 1.28 billion people and 27 million annual birth rates and a fertility rate of 2.72 children per women. In the year 2016, baby and child specific category registered a growth of $15 \%$ and sales reaches the level of INR 20.3 billion. The category is expected to grow at a CAGR of $8 \%$ and predicted to reach a level of INR 29.4 billion by 2021 [1]

India has about 127 million child population and which constitute around $20 \%$ of the $0-4$ year's category population in the world. According to the research report by Technavio, Indian baby care market is expected to grow annually at a rate of $17 \%$ in terms of revenue during 2014-2019 to reach a

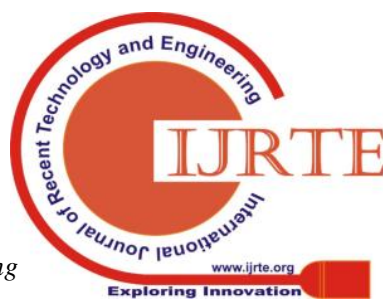


level of $\$ 31$ billion from 14 billion at present. Increasing number of women in labour force, penetration of social networks, better informed parents, life style changes and faster life,

better disposable income, are all considered as factors favoured the growth of baby care market in India.

\section{FACTORS FUELLING THE GROWTH OF BABY CARE MARKET IN INDIA}

\section{A. Large number of infant populations}

India is having the largest infant population base in the age group of 0-4 years and score even higher then China. Despite the fact that birth rates are declining, it is not going to significantly affect the relative position of India in terms of child population in the far long time to come.

\section{B. Increased Urbanization}

India is predominantly rural with $67.2 \%$ of the population residing in rural areas in 2015 says Euro monitor International, 2017. Rural consumers who were mostly living in joint families with grandparents hardly considered baby care products as essential. They always preferred and used home-made natural remedied for baby care. But, with increased urbanization, increased working women population, increased affluence and shortage of time have resulted in the increased demand for baby care products

\section{Rapid economic growth:}

Real GDP grew at an average rate of $8.3 \%$ per year in 2004-2011. Real GDP increased by $7.5 \%$ in 2015 supported by steady gains in consumption, a surge in FDI inflows and fall in oil prices reports Euromonitor international June 2017. Rapid economic growth has contributed to an increased per capita and disposable income resulted in the increased purchasing power of the consumers. Disposable income per capita amounted to Rs.90, 898 in 2016. During the period 2017-2030, disposable income will increase at an average annual rate of $6.6 \%$.

\section{Working mothers:}

The female work participation has increased by an average rate of $4.1 \%$ globally over the last three decades [2]. The job responsibilities let the women with less time to engage themselves in household activities, and created a need for availing convenience products.

\section{E. Increased concern for baby care:}

Transformation from traditional joint family system to nuclear family, have resulted in increased attention and care to the children. As the number of children in the family is less, spending on children has increased. In spite of the income disparity present, parents today are striving to provide their babies with best products for their comfort and healthy growth. They emphasize more on quality and price is not a constraint for them to purchase high quality trust worthy products, increases the scope of baby care industry [2].

\section{ONLINE MARKETING IN INDIA- AT A GLANCE}

An online marketplace (or online e-commerce marketplace) is a kind of e-commerce site where product or service information is provided by multiple third parties, whereas transactions are processed by the marketplace operator [4].

According to AT Kearney 2016, lack of convenience is the primary reason for customers preferring internet shopping over offline store shopping. Also abundant information availability and comparison shopping are also reasons why digital customers prefer online shopping. It is reported by BCG and Retail Association of India that by 2021, India will have more internet users than the total population of six G7 countries. Number of internet users in India have increased tremendously from 170 million in 2013 to 330 million in 2016 and estimated to reach a level of 65-700 million by 2021. Mobile is considered as the most preferred device for accessing internet. As per the report of BCG and RAI report 2017, advancements happed in the technological infrastructure such as falling phone prices, reducing data charges, growing fiber optic network, increased smart phone penetration and rising internet speed are all favouring the growth of online marketing in India. Rising standard of living of customers, increased usage of smartphones and internet, discounted pricing offered, and availability of wide range of products are all driving the growth of e-commerce in the country [5]. The Indian e-commerce industry has been on an upward growth trajectory and is expected to surpass the US to become the second largest e-commerce market in the world by 2034 says Deloitte India \&RAI report, 2019.

\section{ONLINE MARKETING OF BABY CARE PRODUCTS IN INDIA}

According to the report by Euromonitor International 2017, Internet retailing channels has gained more popularity in the baby and child specific products marketing due to the discounted price advantage offered to the customers. During the past couple of years, many new online marketers have entered into the baby care segment with their dedicated websites exclusively catering to the needs of babies and mothers. The major online retailers in the segment are First cry, babyOye, Hopscotch, and My baby cart are exclusively catering the needs of the baby care segment. Retailers like first cry and baby care have set up their offline shops also, to cater the needs of customers who wish to purchase from brick and mortar shops. In addition, other online retail majors such as Amazon, flipkart, snapdeal, etc. are also have entered into the segment by offering wide range of baby care product brands.

Table- I: Major online \& offline baby care product marketers in

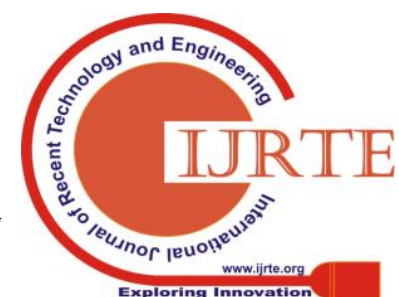


India

\begin{tabular}{|l|l|l|}
\hline \multicolumn{1}{|c|}{ Online retailers } & Horizontal Players & Offline stores/outlets \\
\hline Babyoye.com & Amazon.in & Baby care \\
\hline Bornbabiesonline.com & & Chicco \\
\hline Chicco.in & & Firstcry \\
\hline Firstcry.com & Flipkart.in & Himalaya \\
\hline Hushbaby.com & & Justborn \\
\hline JL Morrison & & Littleshop \\
\hline Kidsstoppers.com & & Mom\&me \\
\hline Littleindia.in & & Patanjali \\
\hline Littleshop & & $\begin{array}{l}\text { Toonz Retail India } \\
\text { Pvt.ltd }\end{array}$ \\
\hline Mybabycart.com & & \\
\hline Pigeon.in & & \\
\hline Toonz.in & & \\
\hline
\end{tabular}

Note: Sample The list is not exhaustive. Compiled by the author from different secondary data sources

Last couple of years has seen a tremendous growth in the eretailing of baby care products. E-retailers are emerging as one of the preferred channel by the shoppers. Internet retailing channels has emerged as most popular channel type for baby and child specific products in 2016 , reports Euromonitor international May 2017. The estimated online market for baby product hovers around Rs. $100-120$ crore and experts opine that it tends to double every 6 to 8 months. Major e -retailers in this segment are Amazon, Flipkart, First cry, Babyoye, Hopscotch.in, hoopos and Snapdeal.

\section{SWOT ANALYSIS OF ONLINE INDIAN BABY CARE PRODUCT MARKET}

\section{A. Strength}

- Increase in disposable income

- Increased awareness and literacy:

- Change in consumer taste and preference:

- Comfort shopping

\section{B. Weakness}

- Low penetration in rural area

- Lack of knowledge regarding online marketing

- Low accessibility

\section{Opportunities}

- Possibility of global marketing

- Cost effectiveness

- Largely unorganized sector

\section{D.Threats}

- International players

- Procedural difficulties

\section{LIMITATIONS AND DIRECTIONS FOR FUTURE RESEARCH}

Present study is solely based on secondary data extracted from published articles, websites, and reports by research organizations, expert's interview reports. Dearth of literatures pertaining to the topic may have reflected in the depth of the study. Further, no specific baby product category or retailer has been selected in the present study, hence, only a generalized picture was given. So, there is a scope for future research by focusing on online marketing of particular product category such as baby cosmetics, toiletries, toys, apparels etc., and rely heavily on primary data so as to present more updated and coherent picture about the happenings in the industry. In addition, future researches concentrating on consumer aspects of online marketing of baby care products will help the marketers in understanding aspects like consumer perceptions and satisfaction with respect to the online marketing strategy in the baby care segment.

\section{REFERENCES}

1. Aswathy, R., \& Chandrasekar, K. (2019). Baby and child specific product markets in the Asia Pacific region: A comparison between India and China. In M. Soundarapandian, Opportunities and challenges in the contemporary management practices (pp. 25-31). Tamilnadu: Maya publishers.

2. Bindhu, H., \& Prasad, D. (2017). Indian baby care market: an overview. International Journal of Economic and Business Review, 53-58.

3. Mishra, H. G., \& Singh, A. (2011). Variables discriminating consumption pattern of baby care products in adults of jammu region. International conference on economics and finance research (pp. 345-347). Singapore: iacsit press.

4. Pinakapani, p., \& chandana, k. S. (2019). Swot analysis of online baby care product. International journal of research in engineering, science and management, 163-165.

5. Suginraj, m. (2017). Growth of online marketing in india- a study. International journal of research in management \& business studies, 9-14

6. Https://www.atkearney.com/strategy-and-top-line-transformation/article?/ a/digital-marketing-time-to-grow-up

7. Https://www.business-standard.com/article/management/online-shoppingto-boost-baby-care-segment-114110200597_1.html

8. Https://www2.deloitte.com/content/dam/deloitte/in/documents/consumerbusiness/in-consumer-rls-2019-noexp.pdf

9. HYPERLINK

"http://www.euromonitor.com/baby-and-child-specific-products-in-asia-pa cific/report"

Published By:
Blue Eyes Intelligence Engineering Exploring innovation
\& Sciences Publication


Http://www.euromonitor.com/baby-and-child-specific-products-in-asia-pa cific/report

10. Http://www.euromonitor.com/baby-and-child-specific-products-in-india/r eport

11. Http://www.euromonitor.com/baby-and-child-specific-products-in-china/r eport

12. https://www.rai.net.in/E-Mailers/Knowledge-Report-RLS-2018/Decoding -Value-Creation-in-Retail-RAI-BCG.pdf

\section{AUTHORS PROFILE}

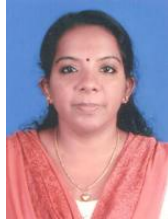

Aswathy.R is currently a Ph.D Research Scholar in the University of Kerala. She has eight years of working experience in the field of teaching there by moulding the MBA graduates. She is also an UGC Senior Research Fellow, who is a M.Phil degree holder from Mahatma Gandhi University, Kerala. Aswathy has four publications in popular jounals in the area of marketing and have presented five papers in varied national seminars and conferences

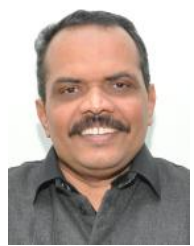

Dr.K.S Chandrasekar is currently the Professor and Dean of Institute of Management in Kerala. He has been placed in many elite positions in the academic front,Chairman-ISTD Trivandrum Chapter, Vice Chairman of Centre of Management, Former Head of the Department \& Registrar in-charge of University of Kerala., Chairman of Board of Studies in Business Management etc to name a few. His scholarly prowess extends to multitudinal fields of academics which is shown through his qualifications in diverse areas such as M.B.A, M.S Psychology and Counseling, Ph.D, Post doctoral CFM, CPET, PGDHP. He has produced 54 Ph.D's and is presently guiding 8 Ph.D Research Scholar in Management, University of Kerala. Dr.Chandrasekar has made his publications in several popular national and international journals, conceptualised study materials,books etc. for various universities and also have involved in the structuring, planning and launching process of various courses for institutions across India. His fields of specialisation extend from various sector of marketing to organizational behaviour, training and development etc. He is a recipient of various accolades; Gold medalist and best academician of the year (2006), Life Time achievement awards (2013 \& 2015), Best Paper winner (2015) etc.to cite a few. 